\title{
PERKEMBANGAN KOTA MADIUN SEBAGAI KOTA GADIS TAHUN 2000-2013
}

\author{
Yudi Hartono, Dodeik Phrasetyo Utomo, Yuli astutik* \\ Dewi Sugiarti, Intan Permata Sari*
}

\begin{abstract}
Abstrak
Kota Madiun adalah sebuah kota berpenduduk kurang lebih 170.000 jiwa terletak di bagian barat Provinsi Jawa Timur. Kota Madiun sesuai dengan visinya menjadi Kota Perkembangan Perekonomian Bagian Barat Provinsi Jawa Timur dengan mengedepankan tiga indikator perkembangan laju perkonomian yaitu "GADIS" yang memiliki kepanjangan Kota Perdagangan, Pendidikan, dan Industri.

Penelitian ini akan mengungkap pola perkembangan Kota Madiun sebagai Kota perdagangan, pendidikan, dan industri. Metode Penelitian kualitatif deskriptif. Teknik pengumpulan data menggunakan metode observasi, wawancara, dan studi pustaka, Teknik keabsahan data menggunakan triangulasi dan analisis data menggunakan analisis interaktif oleh Milles dan Hubberman.

Kota Madiun sejak tahun 2000 mulai berkembang pesat dengan mengedepankan banyak pembangunan di tiga bidang perdagangan, pendidikan, dan industri dengan masing-masing menuai hasil PAD Tahun 2010 hingga Rp. 41.757.000.000. Hasil tersebut didapat dari hasil perdagangan baik di bidang hasil panen pertanian/perkebunan, hasil perdagangan pasar tradisional/ritel/modern, 7 industri besar di Kota Madiun, dan sekolah-sekolah dengan pendidikan berkualitas mulai SD hingga Perguruan Tinggi.
\end{abstract}

\section{Kata Kunci: Pola Perkembangan, Kota}

\section{Pendahuluan}

Indonesia merupakan sebuah negara kepulauan terbesar di dunia dengan hampir kurang lebih ada 30.000 pulau di wilyah NKRI dan kurang lebih ada 13.000 pulau yang berpenghuni, dengan banyaknya pulau Indonesia menjadi negara yang sangat kaya akan banyak sumber daya alam yang melimpah, sebagai negara kepulauan dapat diakui bahwa sumber daya yang ada di Indonesia merupakan salah satu penyumbang perekonomian terbesar seperti dari hasil kekayaan alam meliputi minyak bumi, emas, batu bara, timah, biji besi, dll. Bahkan dari panorama alam yang dimiliki bisa menjadi sumber devisa negara melalui pariwisata, banyak wilayah di Indonesia yang memiliki pemandangan alam yang menakjubkan yang dikunjungi banyak wisatawan mancanegara dan menjadi salah satu penyumbang devisa negara dan yang paling banyak menyumbang devisa negara meliputi Bali, NTB, Papua Barat, Sulawesi Utara, Yogyakarta, Sumatra Utara, dll. Peningkatan ekonomi suatu negara dapat melambangkan seberapa jauh pemerintah negara tersebut mampu mengelola apa potensi yang dimiliki negaranya.

Berbicara mengenai ekonomi Indonesia juga banyak bergabung dengan

* Yudi Hartono adalah Dosen Pendidikan Sejarah IKIP PGRI MADIUN

* Dodeik Phrasetyo Utomo dan Yuli Astutik adalah mahasiswa Pendidikan Sejarah IKIP PGRI MADIUN

* Dewi Sugiarti dan Intan Permata Sari adalah mahasiswa PGSD IKIP PGRI Madiun 
sejumlah organisasi yang menangani perekonomian seperti World Economic Forum, G-20, dll. Meskipun sebagai negara berkembang ekonomi Indonesia terbukti mampu bersaing dengan negara berkembang lain khususnya di asia tenggara, begitupun dinamika ekonomi Indonesia sangat banyak banyak proses perubahan terkait kebijakan perekonomian Indonesia, sangat kompleks krisis-krisis ekonomi yang pernah memukul Indonesia di akhir abad ke 20 menjadi simbol awal pembangunan sendi-sendi awal perkonomian Indonesia hingga sekarang Indonesia mampu bersaing dengan Australia dalam usaha meningkatkan perekonomian negaranya.

Kemudian merunut dari salah satu tujuan jangka panjang pembangunan ekonomi adalah pembangunan ekonomi yang menjadi fokus pembangunan nasional yang merujuk pada peningkatan sumber daya manusia, kemauan teknologi di masa kini diharapkan mempermudah peningkatan kemampuan masyarakat dalam mengelola ekonomi agar mampu bersaing dengan negara-negara maju. Tetapi dalam membuat kebijakan terhadap pengembangan teknologi hendaknya mempertimbangkan beberapa dinamika yang ada di masyarakat antara lain sumber daya yang dimiliki, masalah-masalah yang dihadapi dan tujuan dari pembangunan itu sendiri. Menurut Mulyadi Subri menjelaskan mengenai ekonomi sumber daya manusia adalah ilmu yang diterapkan dengan menganalisis pembentukan dan pemanfaatan sumber daya manusia yang berkaitan dengan pembangunan ekonomi (Mulyadi Subri.2002:1).

Menengok kondisi di daerah pemerintah daerah juga memiki sumbangan besar untuk pembagunan perekonomian negara, dengan kebijakan yang dikeluarkan pemerintah terkait ekonomi yang kemudian bisa diteruskan menjadi peraturan daerah (Perda) pemerintah diharapkan mampu melaksanakan proses tujuan pembangunan ekonomi terutama di daerahnya, Oleh karena itu untuk tujuan pembangunan ekonomi di daerah sebenarnya terdapat banyak pilihan diantaranya melakukan inventasi sumber daya manusia yang dimaksudkan adalah dengan memberikan fasilitas pendidikan dan pelatihan kerja. Akan tetapi investasi SDM ini memilki kendala antara lain prosesnya adalah untuk jangka panjang dan mahal sehingga hasilnya baru akan dapat dilihat ada pada jangka lama juga kemudian faktor setinggi apa pendidikan yang ditempuh SDM juga menjadi kendala sejauh mana SDM mampu membangun ekonomi, tetapi hal tersebut dapat ditutupi dengan mengadakan pelatihan-pelatihan yang terarah, bersifat short-term dan dilakukan secara konsisten dengan orientasi dan kebutuhan yang terus menerus disesuaikan dengan perubahan yang terjadi, merupakan salah satu pilihan yang murah yang berhasil guna bagi 
perkembangan ekonomi derah demi terwujudnya pembangunan ekonomi nasional.

Salah satu daerah yang membantu tercapainya proses pembangunan ekonomi adalah Kota Madiun, Kota Madiun adalah sebuah kota kecil berpenduduk kurang lebih 300.000 orang Madiun berada di tengah posisi sebagai wilayah dengan jalur yang menghubungkan antara provinsi Jawa Timur-Jawa Tengah-Yogyakarta sebagai kota penghubung 3 provinsi Madiun merupakan kota persinggahan bagi sejumlah kegiatan penting di 3 provinsi terutama di bidang perdagangan dan industri dengan dijuluki sebagai "KOTA GADIS" yang berarti Kota Perdagangan dan Industri, Madiun menjadi kota yang diperhitungkan tingkat perekonomiannya selain memiliki jumlah penduduk relative konsumtif, masyarakat madiun secara umum saat ini merupakan gambaran dari masyarakat modern di kota meskipun jauh dari perkembangan ekonomi di ibukota, seperti pendapat yang diungkapakan oleh Daldjoeni sabagaimana apa yang terdapat di kota-kota di negara barat akan menular di negara-negara berkembang, disitu orang tak perlu bekerja seminggu berkat kemajuan teknologi, ada berbagai sarana rekreasi, hiburan, olahraga,dll menjadikan masyarakatnya konsumtif, pendidikan generasi muda makin banyak menghabiskan waktu terdapat sarana komunikasi dan transportasi, ekonomi dengan jasa dan perdagangan menjadi lebih penting dari pada produksi barang (Daldjoeni.198:32). Sementara Soekanto (2002) menekankan pada kondisi sosial ekonomi mengungkapkan bahwa sosial ekonomi merupakan posisi sosial dalam masyarakat berkaitan dengan orang lain dalam arti lingkungan pergaulan, prestasinya, dan hakhak dalam hubunganya terkait sumber daya (Risty Nikiuluw: Jurnal Pendidikan: 2011: 15). Melihat dari pendapat diatas dapat dikatakan bahwa Madiun juga menjadi wilayah potensial untuk dikembangakan menjadi sentra ekonomi maju di wilayah eks-karesidenanan Madiun.

Memiliki penduduk hampir mencapai setengah juta jiwa, kondisi lapangan pekerjaan yang seimbang menjadikan Madiun kota dengan pertumbuhan ekonomi yang baik. Tapi tentu keberhasilan ini tak jauh dari bagaimana peranan pemerintah daerah dalam mengola perekonomian sehingga terwujud perekonomian Madiun yang kuat, potensial, dan bersaing, Tapi jika dirunut dari masa lalu tentu perjuangan menuju kebangkitan Madiun di bidang ekonomi butuh kerja keras, tanaga,dan waktu yang panjang utnuk mewujudkan Kota Madiun menjadi seperti ini. Jika merunut dari perkembanganya, ekonomi Madiun mulai menguat pada dekade awal 2000-an atau awal abad ke-21 sehingga dalam situasi dan kondisi seperti ini menarik untuk diteliti tentang Pola 
Perkembangan Kota Madiun Sebagai Kota Gadis Tahun 2000-2013.

\section{Tinjauan Pustaka}

\section{A. Sejarah dan Pengertian Kota}

Pada mulanya, kota merupakan konsentrasi rumah tangga di pinggir-pinggir sungai yang diorganisasi mengelilingi penguasa atau biasanya pemimpin agama atau pendeta gereja yang kemudian diteruskan oleh kelompok pendeta yang menyelenggarakan pengendalian yang sistimatis dan kontinyu terhadap panen, tenaga kerja dan lain-lain. Masih dapat juga ditelusuri bahwa kota modern di barat pada abad pertengahan dan bahkan sebelum revolusi industri umumnya masih tergantung dari sistem pertanian yang notebene belum memakai alat mesin disamping beberapa kota yang sekaligus memang menjadi pusat perdagangan Nasional dan Internasional. Keadaan tersebut menjadi sebab kota berkembang sangat terbatas dan bila kota bertumbuh di luar batas kemampuan suplai hasil pertanian (makanan) dari "hinterland" (daerah sekitarnya) maka kota tersebut akan mengalami kesulitan makanan; dan untuk mempertahankan eksistensi pertumbuhan tersebut sering diperlakukan penaklukan daerah sekeliling atau daerah lain demi memperbesar suplai bahan makanan. Keadaan inilah yang sering dilakukan oleh penguasa kota di Romawi dan Yunani dahulu.
Setelah revolusi industri, kota di barat berkembang dengan sangat pesat dan merupakan asal-usul urbanisasi yang paling berarti. Penduduk kota bertambah dengan drastis dan penduduk desa, terutama yang dekat kota berkurang. Sebelum revolusi industri, pertumbuhan dan perkembangan kota lambat dan bahkan konstan. Setelah revolusi industri pertambahan penduduk bagaikan meledak hingga untuk pertama kalinya kota-kota di barat melebihi kemampuan kota yang real, yaitu mulai dari penyediaan perumahan yang layak, sarana pendidikan, lapangan kerja dan tempat rekreasi dan lain-lain.

Dari peninjauan sejarah perkembangan dan pertumbuhan kota secara spesifik diperoleh gambaran mengenai hal-hal yang menyangkut: proses perkembangan dan pertumbuhan kota, faktor-faktor penggerak perkembangan dan pertumbuhan kota, dan kemungkinankemungkinan yang dapat dipakai didalam usaha pengarahan dan penyusunan arah dan besarnya perkembangan dan pertumbuhan kota. Studi sejarah perkembangan dan pertumbuhan kota yang spesifik ini jelas akan merupakan bagian yang penting didalam penentuan kebijaksanaan dan pertimbangan didalam perencanaan untuk perkembangan kota tersebut dimasa mendatang. Dari sejarah mengenai perkembangan dan pertumbuhan kota dapat dianalisa apakah pola kecendrungan perkembangan dan 
pertumbuhan yang berlaku sekarang itu mempunyai nilai yang negatif ataukah positip untuk perkembangan kota selanjutnya. Apabila sifat dari pola dan kecenderungan perkembangan dan pertumbuhan kota itu negatif maka didalam kebijaksanaan perencanaannya perlu pengarahan kearah lain sedemikian rupa sehingga perkembangan dan pertumbuhannya dapat diarahkan kepada usaha-usaha perbaikan.

Perkembangan kota secara umum menurut Branch (1995) sangat dipengaruhi oleh stuasi dan kondisi internal yang menjadi unsur terpenting dalam perencanaan kota secara komprehensif. Namun beberapa unsur eksternal yang menonjol juga dapat mempengaruhi perkembangan kota. Beberapa faktor internal yang mempengaruhi perkembangan kota adalah :

1) Keadaan geografis mempengaruhi fungsi dan bentuk fisik kota. Kota yang berfungsi sebagai simpul distribusi, misalnya perlu terletak di simpul jalur transportasi, dipertemuan jalur transportasi regional atau dekat pelabuhan laut. Kota pantai, misalnya akan cenederung berbentuk setengah lingkaran, dengan pusat lingkaran adalah pelabuhan laut.

2) Tapak (Site) merupakan faktor-faktor ke dua yang mempengaruhi perkembangan suatu kota. Salah satu yang di pertimbangkan dalam kondisi tapak adalah topografi. Kota yang berlokasi didataran yang rata akan mudah berkembang kesemua arah, sedangkan yang berlokasi dipegunungan biasanya mempunyai kendala topografi. Kondisi tapak lainnya berkaitan dengan kondisi geologi. Daerah patahan geologis biasanya dihindari oleh perkembangan kota.

3) Fungsi kota juga merupakan faktor yang mempengaruhi perkembangan kotakota yang memiliki banyak fungsi, biasanya secara ekonomi akan lebih kuat dan akan berkembang lebih pesat dari pada kota berfungsi tunggal, misalnya kota pertambangan, kota yang berfungsi sebagai pusat perdagangan, biasanya juga berkembang lebih pesat dari pada kota berfungsi lainnya;

4) Sejarah dan kebudayaan juga mempengaruhi karekteristik fisik dan sifat masyarakat kota. Kota yang sejarahnya direncanakan sebagai ibu kota kerajaan akan berbeda dengan perkembangan kota yang sejak awalnya tumbuh secara organisasi. Kepercayaan dan kultur masyarakat juga mempengaruhi daya perkembangan kota. Terdapat tempat-tempat tertentu yang karena kepercayaan dihindari untuk perkembangan tertentu.

5) Unsur-unsur umum seperti misalnya jaringan jalan, penyediaan air bersih berkaitan dengan kebutuhan masyarakat luas, ketersediaan unsur- 
unsur umum akan menarik kota kearah tertentu.

Menurut Ilhami (1988) sebagian besar terjadinya kota adalah berawal dari dari desa yang mengalami perkembangan yang pasti. Faktor yang mendorong perkembangan desa menjadi kota adalah karena desa berhasil menjadi pusat kegiatan tertentu, misalnya desa menjadi pusat pemerintahan, pusat perdagangan, pusat pertambangan, pusat pergantian transportasi, seperti menjadi pelabuhan, pusat persilangan/pemberhentian kereta api, terminal bus dan sebagainya.

Pengertian kota menurut Dickinson (dalam Jayadinata, 1999) adalah suatu pemukiman yang bangunan rumahnya rapat dan penduduknya bernafkah bukan pertanian. Suatu kota umumnya selalu mempunyai rumah-rumah yang mengelompok atau merupakan pemukiman terpusat. Suatu kota yang tidak terencana berkembang dipengaruhi oleh keadaan fisik sosial.

\section{B. Pola-Pola Perkembangan Kota}

Sesuai dengan perkembangan penduduk perkotaan yang senantiasa mengalami peningkatan, maka tuntutan akan kebutuhan kehidupan dalam aspek ekonomi, sosial, budaya, politik dan teknologi juga terus mengalami peningkatan, yang semuanya itu mengakibatkan meningkatnya kebutuhan akan ruang perkotaan yang lebih besar. Oleh karena ketersediaan ruang di dalam kota tetap dan terbatas, maka meningkatnya kebutuhan ruang untuk tempat tinggal dan kedudukan fungsi-fungsi selalu akan mengambil ruang di daerah pinggiran kota (fringe area). Gejala penjalaran areal kota ini disebut sebagai "invasion" dan proses perembetan kenampakan fisik kota ke arah luar disebut sebagai "urban sprawl" (Northam dalam Yunus, 1994). Secara garis besar menurut Northam dalam Yunus (1994) penjalaran fisik kota dibedakan menjadi tiga macam, yaitu sebagai berikut :

a) Penjalaran fisik kota yang mempunyai sifat rata pada bagian luar, cenderung lambat dan menunjukkan morfologi kota yang kompak disebut sebagai perkembangan konsentris (concentric development).

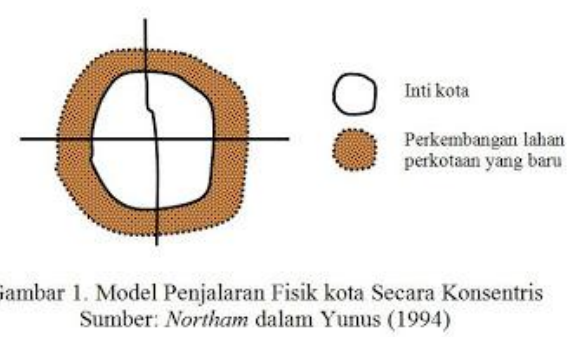

b) Penjalaran fisik kota yang mengikuti pola jaringan jalan dan menunjukkan penjalaran yang tidak sama pada setiap bagian perkembangan kota disebut dengan perkembangan fisik memanjang/linier (ribbon/linear/axial development).

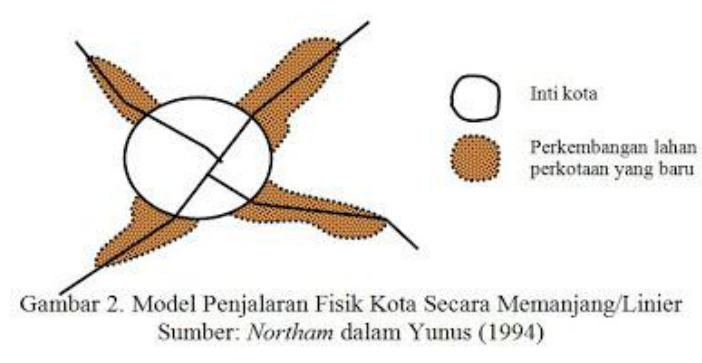


c) Penjalaran fisik kota yang tidak mengikuti pola tertentu disebut sebagai perkembangan yang meloncat (leap frog/checher board development).
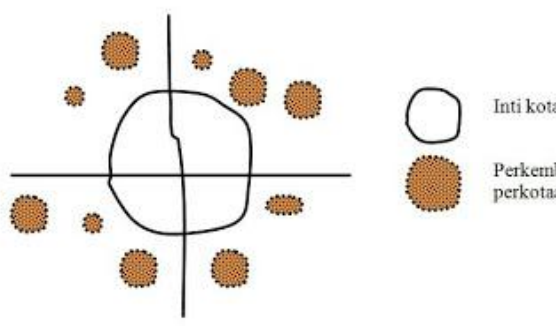

Perkembangan lahan

Gambar 3. Model Penjalaran Fisik Kota Secara Meloncat Sumber: Northam dalam Yunus (1994)

Jenis penjalaran

fisik

memanjang/linier yang dikemukakan oleh Northam sama dengan Teori Poros yang dikemukakan oleh Babcock dalam Yunus (1994), yaitu menjelaskan daerah di sepanjang jalur transportasi memiliki mobilitas yang tinggi, sehingga perkembangan fisiknya akan lebih pesat dibandingkan daerah-daerah di antara jalur transportasi. Pola pemekaran atau ekspansi kota mengikuti jalur transportasi juga dikemukakan oleh Hoyt dalam Daldjoeni (1998), secara lengkap pola pemekaran atau ekspansi kota menurut Hoyt, antara lain, sebagai berikut :

1) Perluasan mengikuti pertumbuhan sumbu atau dengan kata lain perluasannya akan mengikuti jalur jalan transportasi ke daerah-daerah perbatasan kota. Dengan demikian polanya akan berbentuk bintang atau "star shape".

2) Daerah-daerah hinterland di luar kota semakin lama semakin berkembang dan akhirnya menggabung pada kota yang lebih besar.

3) Menggabungkan kota inti dengan kotakota kecil yang berada di luar kota inti atau disebut dengan konurbasi.

Senada dengan pendapat yang dikemukakan oleh Northam dalam Yunus (1994), mengenai perkembangan fisik kota secara konsentris, Branch mengemukakan enam pola perkembangan fisik kota, secara skematis dapat digambarkan sebagai berikut :

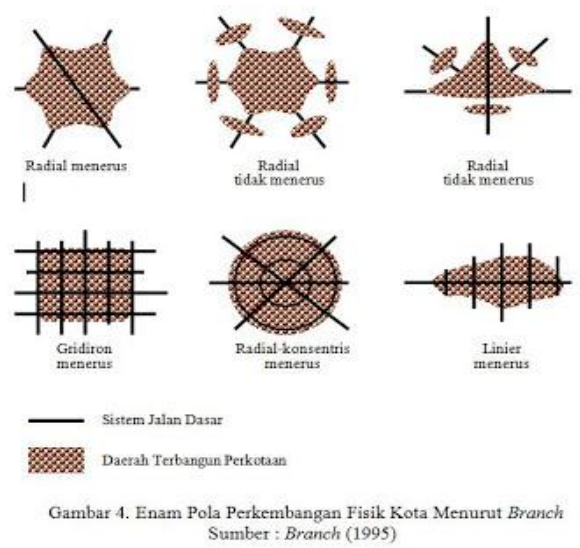

Selanjutnya berdasarkan pada kenampakan morfologi kota serta jenis penjalaran areal kota yang ada, menurut Hudson dalam Yunus (1994) mengemukakan beberapa model bentuk kota, yaitu sebagai berikut :

a) Bentuk satelit dan pusat-pusat baru. Bentuk ini menggambarkan kota utama yang ada dengan kota-kota kecil di sekitarnya terjalin sedemikian rupa, sehingga pertalian fungsional lebih efektif dan lebih efisien. 
b) Bentuk stellar atau radial. Bentuk kota ini untuk kota yang perkembangan kotanya didominasi oleh "ribbon development".

c) Bentuk cincin, terdiri dari beberapa kota yang berkembang di sepanjang jalan utama yang melingkar.

d) Bentuk linier bermanik, pertumbuhan areal-areal kota hanya terbatas di sepanjang jalan utama dan pola umumnya linier. Pada pola ini ada kesempatan untuk berkembang ke arah samping tanpa kendala fisikal.

e) Bentuk inti/kompak, merupakan bentuk perkembangan areal kota yang biasanya didominasi oleh perkembangan vertikal.

f) Bentuk memencar, merupakan bentuk dengan kesatuan morfologi yang besar dan kompak dengan beberapa "urban centers", namun masing-masing pusat mempunyai grup fungsi-fungsi yang khusus dan berbeda satu sama lain.

Berdasarkan pendapat para ahli yang dikemukakan di atas, tentang pola-pola perkembangan fisik kota, pada dasarnya memiliki banyak persamaan. Namun secara umum pola perkembangan fisik kota dapat dibedakan menjadi perkembangan memusat, perkembangan memanjang mengikuti pola jaringan jalan dan perkembangan meloncat membentuk pusatpusat pertumbuhan baru.

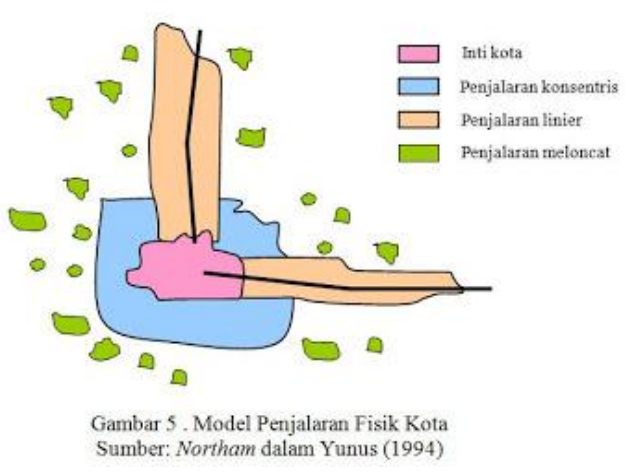

Dalam mengkaji perkembangan fisik suatu kota, menurut Hagget (1970) dapat mengacu pada teori difusi atau teori penyebaran/penjalaran yang mempunyai dua model yang masing-masing memiliki maksud yang berbeda. Model-model tersebut adalah model difusi ekspansi dan model difusi relokasi, dengan penjelasan berikut ini :

1) Model difusi ekspansi (expansion diffusion) adalah suatu proses penyebaran informasi, material dan sebagainya yang menjalar melalui suatu populasi dari suatu daerah ke daerah lain. Dalam proses difusi ekspansi ini informasi atau material yang didifusikan tetap ada dan kadang-kadang menjadi lebih intensif di tempat asalnya. Salah satu contoh proses difusi ekspansi adalah terjadinya pertambahan jumlah penduduk dalam kurun waktu tertentu yang dibedakan dalam dua periode waktu. Dengan demikian dalam ekspansi ruang terdapat pertumbuhan jumlah penduduk, material dan ruang hunian baru. 
2) Model difusi yang lainnya adalah difusi relokasi (relocation diffusion) adalah suatu proses yang penyebaran keruangan, yaitu informasi atau material yang didifusikan meninggalkan daerah asal dan berpindah ke daerah yang baru.

Untuk lebih jelasnya kedua metode difusi tersebut dapat dilihat pada Gambar 6 di bawah ini :
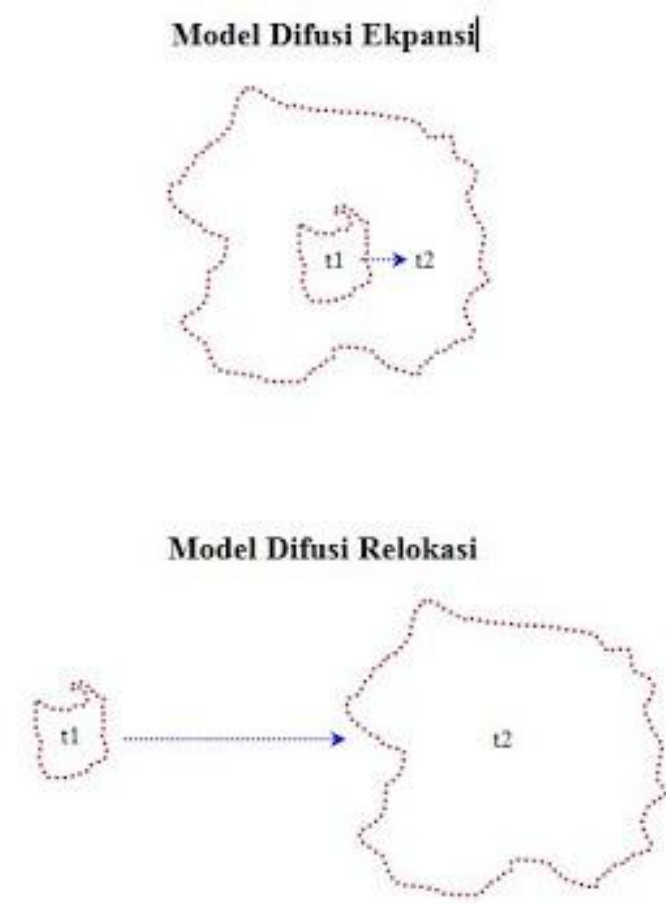

Gambar 6. Model Difusi Ekspansi dan Relokasi Sumber : Hagget (1970)

\section{Faktor-Faktor}

Perkembangan Kota

Penyebab

Menurut Sujarto (1989) faktor-faktor perkembangan dan pertumbuhan yang bekerja pada suatu kota dapat mengembangkan dan menumbuhkan kota pada suatu arah tertentu. Ada tiga faktor utama yang sangat menentukan pola perkembangan dan pertumbuhan kota :

a) Faktor manusia, yaitu menyangkut segisegi perkembangan penduduk kota baik karena kelahiran maupun karena migrasi ke kota. Segi-segi perkembangan tenaga kerja, perkembangan status sosial dan perkembangan kemampuan pengetahuan dan teknologi.

b) Faktor kegiatan manusia, yaitu menyangkut segi-segi kegiatan kerja, kegiatan fungsional, kegiatan perekonomian kota dan kegiatan hubungan regional yang lebih luas.

c) Faktor pola pergerakan, yaitu sebagai akibat dari perkembangan yang disebabkan oleh kedua faktor perkembangan penduduk yang disertai dengan perkembangan fungsi kegiatannya akan menuntut pola perhubungan antara pusat-pusat kegiatan tersebut.

\section{Metodologi Penelitian}

\section{A. Pendekatan dan Jenis Penelitian}

Berdasarkan pada masalah yang diajukan dalam penelitian, dikarenakan data yang dikumpulkan berbentuk kata atau gambaran dari catatan lapangan maka jenis pendekatan penelitian ini yaitu kualitatif. Penelitian Kualitatif menurut Made Wirartha (2006:134) penelitian kualitatif lebih menekankan kepada analisisnya pada proses penyimpulan deduktif dan induktif serta pada analisis terhadap dinamika hubungan antar fenomena yang diamati dengan menggunakan logika ilmiah. 
Jenis penelitian ini adalah penelitian kualitatif deskriptif yang terbatas pada usaha mengungkapkan suatu masalah atau keadaan atau peristiwa sebagaimana adanya sehingga bersifat sekedar mengungkapkan fakta (fact finding). Hasil penelitian ditekankan pada memberikan gambaran secara objektif tentang keadaan yang sebenanrya dari objek yang diselidiki, dan agar manfaat penelitian lebih luas kerap kali pengungkapan fakta dilakukan dengan memberikan interpretasi-interpretasi yang kuat (Hadari Nawawi, 2005:31).

\section{B. Teknik Pengumpulan Data}

1. Metode Observasi

Observasi digunakan untuk menggali data dari sumber data yang berupa peristiwa, tempat atau lokasi, dan benda, serta rekaman gambar. Observasi dapat dilakukan baik secara langsung maupun tidak langsung (Sutopo, 2002:64)

\section{Metode Wawancara}

Menurut Sugiyono

(2010:194) wawancara digunakan sebagai teknik pengumpulan data apabila peneliti ingin melakukan studi pendahuluan untuk menemukan permasalahan yang harus diteliti, dan juga apabila peneliti ingin mengetahui hal-hal dari responden yang lebih mendalam dan jumlah respondenya sedikit/kecil.

\section{Studi Pustaka}

Dalam melakukan penelitian melakukan tinjauan pustaka amatlah penting karena menjadi sumber infomrasi dalam penelitian ini, maka dari itu peneliti melalui Made Winartha membagi jenis sumber pustaka menjadi tiga dengan rinciannya sebagai berikut:

a) Sumber Primer: adalah sumber yang berasal dari catatan tangan pertama dari seorang peneliti yang biasanya di dapati dalam artikel ilmiah, jurnal ilmiah, tesis, yang mana termasuk ke dalamnya terdapat catatan harian, surat, catatan saksi mata, otobiografi, laporan dinas.

b) Sumber data sekunder: misalnya terjemahan, kumpulan ringkasan penelitian (jurnal, artikel, dll), abstrak, publikasi, yang berisi informasi faktual, dan komentar, dll

Sumber data tersier: misalnya buku ajar yang disusun dalam data sekunder dan tingkat kebenaran sumber infomrasi tersebut merupakan fungsi dari jumlah tangan yang dilalui, semakin sedikit maka semakin sedikit pula tingkat kebenaran informasi/data tersebut.

\section{Prosedur Penelitian}

Bahwa tahap-tahap penelitian kualitatif ada tiga yaitu: 1) Menetapkan Fokus Penelitian, 2) Menentukan Setting dan Subjek Penelitian, 3) Pengumpulan data, pengolahan data dan analisis data, 4) penyajian data (Bagong dan Sutinah, 2005:170-174).

\section{Teknik Keabsahan Data}

Triangulasi data (triangulasi sumber) menurut Patton (dalam Sutopo, 2002: 79) 
cara untuk mengarahkan peneliti dalam mengumpulkan data, peneliti wajib menggunakan beragam sumber data yang tersedia karena akan semakin valid kebenaranya apabila berasal dari data yang berbeda sehingga bisa teruji kemantapan dan kebenarannya.

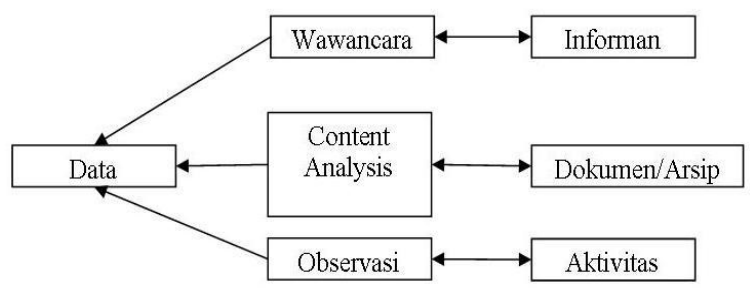

Gambar 3.1. Triangulasi Sumber oleh Sutopo (Sutopo, 2010:80)

\section{E. Teknik Analisis Data}

Menurut Milles and Hubberman (1992:16) analisis data terdiri dari tiga alur kegiatan yang terjadi secara bersamaan yaitu: reduksi data, penyajian data, penarikan kesimpulan/verifikasi.

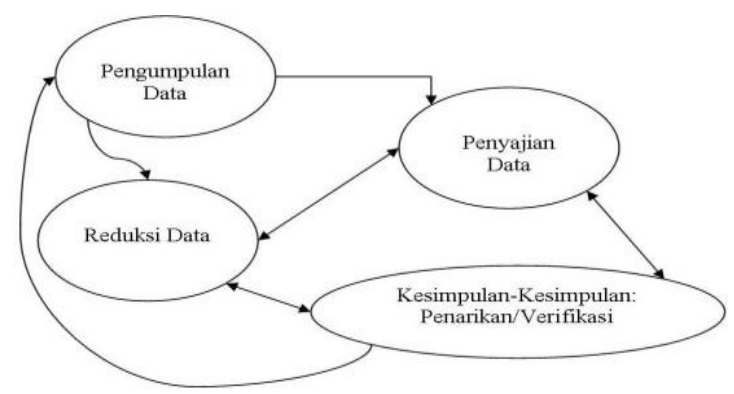

Gambar 3.2 Analisis Data Model Interaktif dari Miles dan Huberman

(Sumber: Milles and Hubberman, 1992: 20)

\section{Hasil penelitian}

\section{A. Tinjauan Singkat Kota Madiun}

1. Geografis

Kota Madiun bagian dari wilayah

Propinsi Jawa Timur bagian barat. Kota ini terletak $169 \mathrm{~km}$ sebelah barat Kota Surabaya dan $114 \mathrm{~km}$ sebelah timur Kota Surakarta. Kota yang terkenal dengan sebutan Kota GADIS (Perdagangan, Pendidikan dan Industri) terletak di dataran rendah, adapun letak astronomis Kota8i7uuuu Madiun terletak di dataran rendah antara $7^{\circ}-8^{\circ}$ lintang selatan atau sepanjang 7,5 $\mathrm{km}$ bentang arah utara selatan, dan antara $111^{\circ}-112^{\circ}$ bujur timur atau sepanjang $6 \mathrm{~km}$ bentang arah barat timur (Badan Pusat Statistik, 2011:1).

Letak geografis Kota Madiun sangat strategis karena terletak pada simpul jaringan jalan raya regional yang menghubungan daerah-daerah di Jawa Timur dengan daerah Jawa Tengah, khususnya menghubungkan Kota Madiun dengan kota-kota besar lainnya yaitu Surabaya dengan Surakarta dan Yogyakarta. Di samping itu Kota Madiun juga dilewati jaringan jalan kereta api lintas utama Pulau Jawa bagian selatan, yang menghubungkan Surabaya - Jakarta lewat Purwokerto dan Surabaya - Bandung. Hal ini disebabkan karena di Kota Madiun terdapat industri kereta api (PT INKA) yang sampai sekarang masih aktif dalam dunia transportasi di tanah air.

Luas wilayah Kota Madiun 33,23 km² yang terbagi menjadi 3 kecamatan, yaitu Kecamatan Manguharjo dengan luas 10,04 $\mathrm{km}^{2}$, Kecamatan dengan luas $12,46 \mathrm{~km}^{2}$ dan Kecamatan Kartoharjo dengan luas 10,73 $\mathrm{km}^{2}$. Kota Madiun terletak pada daratan 
dengan ketinggian 63 meter hingga 67 meter dari permukaan air laut. Daratan dengan ketinggian 63 meter dari permukaan air laut terletak di tengah, sedangkan daratan dengan ketinggian 67 meter dari permukaan air laut terletak di sebelah di selatan.

Secara administrasi wilayah Kota Madiun berbatasan langsung dengan wilayah Kabupaten Madiun dan Magetan dengan batas-batas sebagai berikut : sebelah utara berbatasan dengan Kecamatan Madiun Kabupaten Madiun, sebelah timur berbatasan dengan Kecamatan Wungu Kabupaten Madiun, sebelah selatan berbatasan dengan Kecamatan Geger Kabupaten Madiun dan sebelah barat berbatasan dengan Kecamatan Jiwan Kabupaten Madiun. Menurut klasifikasi desa, 4 kelurahan yang ada di Madiun termasuk desa swadaya, 9 kelurahan termasuk desa swakarsa dan 14 kelurahan termasuk desa swasembada.

\section{Demografi}

Jumlah penduduk kota Madiun pada tahun 2010 adalah 170.964 jiwa. Jumlah penduduk laki-laki sebanyak 82.738 jiwa dan jumlah penduduk perempuan adalah 88.226 jiwa. Untuk lebih jelasnya dapat dilihat ditabel berikut ini :

Tingkat kualitas SDM dapat dilihat dari tinggi rendahnya pendidikan yang ditempuh oleh masyarakat Kota Madiun. Persentase tertinggi lulusan pendidikan SLTA ke atas sebanyak 76,79\%, sedangakan
SLTP sebanyak 9,09\% dan SD kebawaah sebanyak $14,11 \%$.

Tabel 4.1

\begin{tabular}{|c|c|c|}
\hline No & $\begin{array}{c}\text { Tingkat } \\
\text { Pendidikan }\end{array}$ & $\begin{array}{c}\text { Persentase } \\
\text { Jumlah } \\
\text { Penduduk (\%) }\end{array}$ \\
\hline 1 & SLTA ke atas & 79,80 \\
\hline 2 & SLTP & 9,09 \\
\hline 3 & SD ke bawah & 14,11 \\
\hline
\end{tabular}

Komposisi Jumlah Penduduk Berdasarkan Tingkat Pendidikan

Sumber : Badan Pusat Statistik Kota Madiun 2011

Jumlah sekolah di Kota Madiun dari TK sampai SLTA telah cukup memadai. Bahkan jumlah SD dan TK pada tahun 2010 meningkat sejalan dengan banyaknya jumlah murid. Selain meningkatkan sarana dan prasarana Dinas Pendidikan, Kebudayaan, Pemuda dan Olahraga menyelenggarakan program keaksaraan fungsional. Menurut data hasil survey Angkatan Kerja Nasional (Sakernas) tingkat partisipasi angkatan kerja (TPAK) penduduk usia 10 tahun keatas pada tahun 2010 adalah 60,81. Menurut data ini jumlah penduduk Kota Madiun yang bekerja cukup tinggi, yaitu 90,42\% sedangkan sisanya 9,58\% adalah pengangguran.

Tabel 4.2

Persentase Jumlah Penduduk Berdasarkan TPAK

\begin{tabular}{|c|c|c|}
\hline No & $\begin{array}{c}\text { Penduduk Kota } \\
\text { Madiun }\end{array}$ & $\begin{array}{c}\text { Jumlah } \\
\text { (dalam \%) }\end{array}$ \\
\hline 1 & Bekerja & 90,42 \\
\hline 2 & Pengangguran & 09,58 \\
\hline
\end{tabular}

Sumber: Badan Pusat Statistik Kota Madiun 2011 


\section{B. Madiun sebagai Kota GADIS (Perdagangan, Pendidikan, dan Industri) \\ Perdagangan merupakan salah satu} adalah kegiatan dalam rangka pendistribusian produk mulai dari produsen sampai dengan konsumen ,di dalam perdagangan ada sektor- sektor yang dilalui ada suplayer, distributor dan sebagainya. Kota Madiun distribusi produk perdagangan dari produsen sampai ke konsumen lancar ,tidak ada kendala dan dari tahun ke tahun pemerintah kota Madiun mengadakan pengawasan distribusi product, agar pemasarannya ke konsumen tetap berjlan dengan lancar. Kondisi perdagangan di Kota Madiun saat ini sangat kondusif ,artinya konsumen dengan mudahnya mendapatkan product-product yang diinginkan,selain itu produk- produk kebutuhan sehari- hari dan juga merupakan yang dikonsumsi setiap hari, yaitu kebutuhan sekunder,primer dan tersier mudah di peroleh. Jadi perdagangan Kota Madiun saat ini sangat kondusif.

Pada awal taun 2002 memang perkembangannya belum pesat seperti saat ini, bisa dilihat di Kota Madiun kini di sepanjang jalan banyak perdagangan yaitu seperti mall ,ada pasar- pasar modern. Namun demikian pemerintah tetap mengadakan penaataan, dan peran pasar tradisional tetap diminati. Pemerintah ota Madiun taun ini intens melakukan pembinaan dan pengembangan, contoh pasar besar dan pasar Joyo dan Pemerintah Kota Madiun tetap mengijinkan investor masuk dalam rangka menumbuh kembangkan perekonomian Kota Madiun dengan lahirnya pasar- pasar modern dan menambah penghasilan dari sektor perdagangan yang ada di Kota Madiun (wawancara dengan Kepala Bidang Perdagangan)

Industri di Kota Madiun dari tahun ke tahun mengalami peningkatan. Industri di Kota Madiun terdapat industri besar dan industri kecil.Baik dari makanan olahan seperti tempe keripik, madu mongso, enting-enting maupun garmen.Industri besar di Madiun berlokasi di Jalan Basuki Rahmat dan Yos Sudarso. Dimana di sekitar jalan tersebut terdapat pabrik gula Rejo Agung dan INKA ( Industri Kereta Api). Potensi yang ada di madiun dari pertanian tidak bisa diandalkan karena kurangnya bahan baku yang ada disekitar Madiun. Pertanian di Kota Madiun belum bisa membantu menyediakan bahan dasar misalnya dalam industri tempe pertanian Kota Madiun tidak dapat menyediakan kedelai yang cukup untuk pembuatan tempe sehingga membeli dari kota lain. Lokasi industri yang besar di Kota Madiun yaitu jalan basuki rahmat dan jalan yos sudarso. Seperti industri kereta api INKA, pabrik gula Rejo Agung dan disekitar sana rencananya akan dibangun pabrik lagi. Di kawasan Kelurahan Kelun terdapat industri tempe, Kelurahan Nambangan Lor dan Kelurahan Banjarejo terdapat industri tahu 
(Wawancara dengan Kepala Bidang Perindustrian)

Pada dasarnya menurut Bappeda isitlah Kota Madiun sebagai Kota Gadis itu tidak ada dalam visi dan misi Kota Madiun sebagai Kota Gadis, karena mengingat banyak orang bisa berkonotasi negatif terhadap julukan tersebut. Namun untuk lebih jelasnya mengapa Kota Madiun berjuluk demikian bisa ditanyakan kepada bagian pemerintahan, Masalah perkembangan perekonomian Kota Madiun saat itu di awal tahun 2000 sangat baaik, mulai dengan masuknya investor Bappeda sebagai salah satu badan yang mengurusi pembangunan Kota Madiun melihat bahwa pembanguna di Kota Madiun sangat signifikan hal ini dikarenak selain adanya kebijakan yang mengatur adanya pembangunan juga adanya kebijakan dari setiap walikota yang akan menjabat. Pola pembangunan perekonomian Kota Madiun di fokuskan di wilayah-wilayah tiap kecamatan, tidak lagi dipusatkan di Jalan Pahlawan Kota Madiun, karena jalan pahlawan sejak dahulu daerah sentra bisni di Kota Madiun, tujuan utama mengapa pembanguna perekonomian Kota Madiun di bagi ke wilayah tiap kecamatan adalah untuk memberikan kesempatan terbukanya banyak lapangan kerja di sana. Kemudian juga memberikan kesempatan untuk memberikan hiburan, kemudahan transportasi dan juga kemudahan akses public lainnya (Hasil Wawancara dengan Badan Perencanaan Daerah).

Pada dasarnya penyebutan Kota Gadis kurang tepat bagi Kota Madiun dikarenakan definisinya yang kontras dan beragam, oleh karena itu sebaiknay gunakan kata Kota Perekonomian Jawa Timur Bagian Barat. Dispenda sebagai salah satu dinas yang mengurusi pajak restribusi di di Kota Madiun seperti pajak hotel, restaurant, mall, dan pajak-pajak lainya yang masuk ke dalam PAD, wilayah Kota Madiun sama-sama bisa menyangga perekonomian karena sejak dulu pola pembangunan perekonomian Kota Madiun tidaklah terpusat dalam satu wilayah namun menyebar ke seluruh Kota sehingga pendapatan yang diterima pun sama besarnya. Bukti-bukti semua itu bisa dilihat di dalam Madiun Dalam Angka karena di situ semua terdapat laporan pajak dan juga beraneka jenis pajak yang sudah mewakili Dispenda. Jika dilihat dari tahun Kota Madiun mulai berkembang sangat pesat sejak 5 tahun terakhir sejak Walikota Bambang Irianto menjabat sebagai Walikota Madiun.

Kondisi perdagangan dan industri di Madiun sangatlah fluktuatif yang namanya pangsa pasar itu juga bisa naik dan turun untuk bisa menjaga jika terjadi penurunan maka akan di bantu dahulu dari PAD, cara untuk meningkatkan PAD jika perdagangan dan industyri melemnah dengan mendatrangakn investor ke Kota Madiun maka ada kemungkinan PAD Kota akan 
Meningkat (Hasil Wawancara dengan Dinas Pendapatan Daerah).

Menurut Dinas Pendidikan secara singkat menurutkan bahwa perkembangan perekonomian Kota Madiun juga didukung dengan banyak berdirinya sekolah-sekolah tinggi, yang menyebabkan juga tumbuhnya sektor ekonomik baru yaitu kuliner, banyak pedagang-pedagang jajanan kecil mulai bermunculan terutama disekitar kampus atau sekolah-sekolah tinggi yang ada di Madiun, selain pedagang kecil, sektor perekonomian di Kota Madiun juga meningkat karena banyak mahasiswa yang berasal dari luar kota yang membutuhkan tempat kost oleh karena itu tumbuhnya banyak tempat kost juga membuat sektor perekonomian Kota Muncul demikian juga toko serba ada juga mulai banyak bermunculan di daerah di sekitar tempat pendidikan (Wawancara dengan Dinas Pendidikan)

\section{Pembahasan}

Berdasarkan paparan data di atas dapat dilihat bahwa Madiun merupakan kota yang potensial untuk perkembangan perekonomian, karena hal tersebut Kota Madiun dibuktikan semenjak selepas tahun 2000 Kota Madiun terus mengalami peningkatan di berbagai sektor, menurut Badan Pusat Statistik Kota Madiun sektorsektor utama yang menyebabkan Kota Madiun menjadi pusat perekonomian di wilayah barat provinsi jawa timur yakni: Geografi, Iklim, Pemerintahan,Penduduk, Tenaga Kerja, Pendidikan Pertanian, Industri, Transportasi, Komunikasi, Perhotelan, dan sarana rekreasi keluarga.

Dalam pemerintahan beberapa walikota selama dekade ini yaitu Walikota Achmad Ali, Kokok Raya, dan Bambang Irianto telah diputuskan bahwa yang menjadi pokok perkembangan perkonomian kota madiun ditinjau dari Perdagangan, Pendidikan, dan Industri sehingga bagian Pemerintahan Kota Madiun memberi sebutan Kota Madiun sebagai Kota Gadis yang memiliki kepanjangan Kota Perdagangan, Kota Pendidikan, dan Kota Industri.

Di tahun 2000 Pembangunan wilayah Kota Madiun dilaksanakan sesuai pengembangan kawasan berdasar Tata Ruang dan Tata Kota serta kondisi lingkungan yang bisa mendukung pelaksanaan pembangunan, dalam pelaksanaan pembangunan sesuai dengan tata ruang terbagi dalam 3 (tiga) kawasan tersebut meliputi :

- Kawasan Industri: berada disebelah timur sungai, di utara pusat kota.

- Kawasan Perdagangan: disebelah barat sugai Madiun

- Kawasan Perkantoran/Pendidikan: Berada disebelah timur Sungai Madiun, di sebelah jalan utama Serayu.

Seiring dengan pelaksanaan pembangunan pemerintah Kota Madiun 
terus berupaya untuk meningkatkan pelayanan kepada masyarakat dengan pembangunan jembatan outer ring road barat yang terletak di Kelurahan Patihan dan Sogaten, hal ini menunjukan adanya keinginan Pemerintah Kota Madiun untuk bisa menjadikan satu Kota Madiun yang sebelumnya terbelah menjadi dua yaitu timur dan barat.

Dengan adanya jembatan ini pelayanan kepada masyarakat sebagai sentra pengembangan kota. Ke depan kota Madiun akan memiliki 7 jembatan penghubung dan apabila berfungsi secara normal pendekatan wilayah akan dicapai dengan baik dan tidak ada perbedaan yang menyolok.

Di tahun 2001 pemgembangan untuk perekonomian kota madiun dipusatkan di jalan pahlawan madiun dengan pembangunan sejumlah sarana rekreasi keluarga seperti Mega Mall, Perhotelan, serta pembangunan sejumlah sarana dan prasarana pendukung seperti lahan parkir. Pemerintah Kota Madiun telah menetapkan Jalan Pahlawan Kota Madiun sebagai Distrik/ Pusat Bisnis Kota Madiun dengan berdirinya sejumlah Mall, Perbankan, dan Hotel Berbintang di Jalan Pahlawan, sementara di kawasan barat kota mulai dibangun proses pembangunan jalan tembus Jiwan - Terminal Purboyo Madiun yang akan mempersingkat jarak tempuh sejumlah bus maupun MPU untuk tidak kembali masuk ke dalam kota kecuali bus kecil hal ini diperhitungkan juga untuk mengurangi beban muatan jembatan manguharjo sebagai jembatan utama lalu lintas dari dan keluar kota madiun.

Di tahun 2001 pendapatan perekonomian Kota Madiun masih di bilang sedikit hanya dibantu dengan sejumlah pusat pendapatan lokal seperti Pasar Besar Madiun, Pasar Sleko, Distrik Jalan Kutai, RSUD. Dr Soedono Madiun, Plaza President Madiun, Pendapatan dari sejumlah hotel juga sanggat sedikit terhitung di tahun 2000 - 2003 hanya terdapat 31 hotel di Kota Madiun yang menyokong perekonomian Kota Madiun sedikitnya fasilitas tersebut dianggap kurang menarik investasi besar di kota Madiun. Oleh karena itu Pemkot Madiun memutuskan bahwa perekonomian Kota Madiun akan di fokuskan pada pengembangan Industri dengan berfokus pada Industri Kereta Api (INKA) sebagai pendapatan terbesar pemerintah Kota Madiun dari bidang Industri.

Di tahun 2002 Pemkot Madiun kembali dilegakan dengan pembangunan sejumlah sarana pendapatan perkonomian baru di Kota Madiun yaitu diresmikanya sejumlah Mega Mall di kota Madiun oleh Walikota Achmad Ali pertama diresmikannya Pasaraya Sri Ratu sebagai mall termegah 5 Lantai pertama di Keresidenan Madiun, kemudian penetapan sejumlah Hotel berbintang di Madiun seperti Hotel Merdeka merupakan Hotel 
Berbintang 4 pertama di Karesidenan Madiun.

Kemudian pembangunan sejumlah pusat perekonomian baru semakin gencar dilaksanakan berikutnya pembangunan juga fokus pada dunia pendidikan untuk mendapat pendapatan daerah yang berlebih bagi kota Madiun dari tahun ke tahun jumlah penduduk yang makin meningkat membuat Pemkot Madiun harus memutar otak untuk kembali membangun sarana pendidikan baru dimulai dari progress SMA International Standart bagi SMAN 2 dan SMAN 3 serta pembangunan sejumlah Sport Center sebagi sarana pengembangan minat dan bakat siswa-siswi bahkan mahasiswa di Kota Madiun sperti renovasi Stadion Wilis di tahun 2002-2003 lalu progress pembangunan kembali pasar besar madiun yang terbakar di tahun 2001.

Di tahun 2003 perekonomian Madiun kembali menguat dengan diresmikanya sebuah Mall sebagai pusat rekreasi keluarga MATAHARI Mall (Madiun Plaza, Sekarang) menjadi penyumbang perekonomian di bagian timur kota madiun

Progress kembali gencar dilakukan oleh Walikota Kokok raya dengan pembangunan sejumlah sarana pemukiman/ perumahan baru di kawasan timur yang sekarang banyak dihuni kaum elit di madiun kemudian planning pemekaran Kampus Ikip Pgri Madiun juga menjadi pemikiiran sendiri bagi Pemkot Madiun, pengembangan sejumlah sarana dan prasana kembali dilakukan sebagaian terlihat jelas pada pemugaran Alun-Alun Madiun di tahun yang sama sebagai langkah usaha untuk mempercantik Kota Madiun, sebagai pusat pengembangan perekonomian di wilayah barat jawa timur. Kota Madiun dari tahun 2000 hingga 2003 terus berupaya utnuk mengembangkan daya tarik tamu asing mamupun domestik ke kota Madiun dengan mengadakan sejumlah event seperti Perayaan Ulang Tahun Kota Madiun yang intensif diadakan sejak 2003 hingga sekarang, medatangkan sejumlah artis saat pergantian tahun menjadi retribusi pariwisata tersendiri bagi Pemkot Madiun, kemudian sejumlah Lomba bertaraf nternasional seperti Tour de Java - Bali yang rutin membawa pembalap-pembalap sepeda luar negeri ke Madiun juga menjadi kontribusi tersendiri bagi Pemerintah Kota Madiun.

Tahun 2004 kembali progress sarana perkembangan perekonomian Kota Madiun kembali sejumlah sarana untuk mengembangkan perekonomian Kota Madiun Walikota Madiun Kokok Raya kembali membuat keputusan dengan membangun sejumlah sarana hiburan dan rekreasi bekerjasama dengan investor membangun kembali Timbul Jaya Plaza yang lama mangkrak kemudian pengembangan wilayah bosbow mejadi pusat rekreasi kuliner keluarga, pembangunan asrama haji, serta 
pembangunan Mall Baru yaitu Carrefour Madiun yang menggunakan lahan bekas Pasar Grosir Madiun, Ekonomi Kota Madiun semakin bergolak dengan diresmikannya Pasar Besar Madiun yang terbakar beberapa tahun silam.

\section{Di akhir tahun 2004 bekerja} dengan sejumlah pengembang melakukan pembangunan perumahan di kawasan selatan dan barat madiunguna menambha sarana pemukiman bagi masyarakat kota madiun,mengundang sejumlah investor besar ke Kota Madiun dengan mengandalkan sejumlah objek wisata di kota-kata lain tapi dengan fasilitas jetset dikota madiun mejadi sarana perkembangan ekonomi kota Madiun.

Di tahun 2005 pengembangan pusat perekonomian terjadi di wilayah seputar Kota Madiun dengan pengembangan sejumlah ruko dan usaha UM - UKM yang akan menghasilkan tenaga kerja yang madiri dan wirausahawan yang tangguh bagi pembangunan perekonomian kota madiun kemudian Pemkot Madiun juga membangun Gedung Pusdiklat di timur Lapangan Gulun sebagai sarana pusat pendidikan, dan pelatihan sejumlah perangkat yang mejadi objek perkembangan ekonomi madiun seperti guru, wirausahawan, mahasiswa, atlit, dll.

Sarana dan prasarana transportasi kembali ditingkatkan dengan membangun sejumlah halt angkutan umum Di wilayah prestis di Kota Madiun, kembali melakukan renovasi dan pembangunan sekolah-sekolah di Kota Madiun sebagai sarana penunjang pendidikan.

Di tahun 2006 Pemkot Madiun fokus terhadap perkembangan peternakan dan tanaman pangan di tahun 2006 merupakan puncak tertinggi pendapatan regional kota dengan pendapatan dari peternakan mencapai 1386 Ton dari lahan pertanian mampu menghasilkan 15.110,48 Ton Padi yang mampu meningkatkan daya beli masyarakat dan pendapatan pemkot secara keseluruhan.

Di tahun 2007 sumber pendapatan perkonomian terbesar berasal dari Industri dan Pusat Perbelanjaan, masyarakat Kota Madiun yang tipikal warga yang konsumtif mempermudah meningkatnya pendapatan pemerintah pembangunan sejumlah Mega Mall dan proyek-proyek lain sebagai sarana peningkatan perekonomian Kota Madiun.

Bertambah banyaknya penduduk dan kebutuhan akan tenaga kerja membuat pemkot Madiun memutuskan untuk makin meperbanyak pembanguna Ruko guna keperlua UM-UKM serta bekerja sama dengan Bank-bank pemerintah untuk memermudah peminjaman guna meningkatkan perekonomian dan kebutuhan akan tenaga kerja.

Di masa-masa akhir pemerintahan walikota Kokok Raya ekonomi madiun tahun 2007 meningkat dengan pendapatan Bruto mencapai Rp. 995.215.000,00 dapat dikatakan hampi satu milyar rupiah dalan 
setahun, saying dalam stus BKPM tidak disebutkan bagaimana dengan laju pertumbuhan di Kota Madiun.

Di tahun 2008 diera baru pergantian kekuasaan walikota masyarakat Kota Madiun dan pemkot Madiun justru diawali dengan kehancuran pusat perekonomian Kota Madiun yaitu kembali terbakarnya Pasar Besar Madiun yang tepat terjadi pada Hari Pemilihan Umum Walikota Madiun 2008 - 2013, Dalam pemilu yang dimenangkan oleh Bambang Irianto seorang pengusaha asal Kota Madiun. Walikota Irianto harus dihadapkan dengan cobaan yaitu pembangunan infrastruktur Pasar Besar Madiun serta pembangunan sejumlah sarana dan prasarana baru.

Dikutip dari Radar Madiun Edisi Cetak 28-12-2009 Kondisi perekonomian Kota Madiun tahun 2010 mendatang diprediksi membaik. Pertumbuhan ekonomi Kota tahun depan diperkirakan juga meningkat.Terutama, sektor properti dan perdagangan.

Dosen ekonomi Universitas Merdeka Madiun Muhammad Imron mengatakan, dari tahun ke tahun jumlah penduduk Kota mengalami peningkatan. Sehingga, kebutuhan rumah layak juga ikut melonjak. Tidak mengherankan jika bisnis perumahan di wilayah setempat berkembang pesat. 'Begitu juga dengan sektor perdagangan. Banyaknya perusahaan ritel yang menanamkan modalnya di Kota Madiun juga membuat perekonomian setempat meningkat. Banyaknya mall di kotamenjadi daya tarik bagi warga di Eks Karesidenan Madiun untuk berbelanja. Saat akhir pekan, pusat-pusat perbelanjaan yang ada di Kota selalu dipadati pengunjung. Mayoritas berasal dari luar kota seperti Ngawi, Caruban, Magetan dan Ponorogo (dalam Radar Madiun, 27/12).

Kondisi itu sebaiknya juga dimanfaatkan pemkot untuk mengangkat perekonomian masyarakat Kota Madiun. Dikatakan, pengusaha ritel juga harus memberikan kesempatan bagi usaha kecil dan menengah untuk berpartisipasi di dalamnya. 'UKM yang ada di wilayah setempat mestnya juga diberi akses untuk menyuplai barang yang dijual di mal sehingga,dikenal dan diminati. Keberadaan jalur Caruban-Ngawi, Imron mengatakan, berpengaruh signifikan terhadap perekonomian Kota Madiun.Kota di bagian barat Provinsi Jawa Timur ini kemungkinan tidak lagi bisa mempertahankan ikonnya sebagai kota transit. Sebab, jalur dari Surabaya ke Jawa Tengah atau sebaliknya, tidak lagi melewati Kota Madiun. Kondisi ini harus segera diantisipati oleh pemkot. Salah salah satunya mempermudah regulasi berinvestasi (Radar Madiun Edisi Cetak 2812-2009).

Berbagai kebijakan ketat dan berani diambil oleh Walikota dengan meningkatkan APBD Kota Madiun guna meningkatkan perekonomian dan 
menguatkan stabilitas perekonomian Madiun.

Tabel 5.1

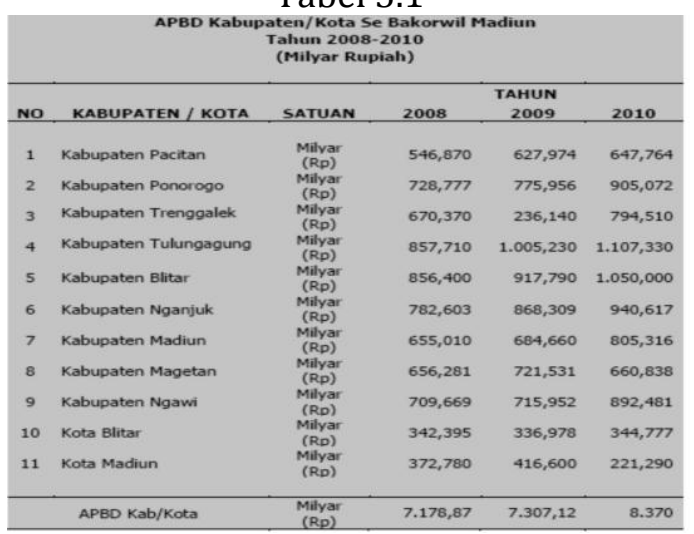

Sumber: Bakorwil Madiun

Di Tahun 2010 APBD Kota Madiun

turun secara signifikan sebanyak \pm 200

Milliar Rupiah hal ini terjadi karena sejumlah event prestige yang tengah disiapkan Pemkot Madiun di tahun 20102011 sehingga memerlukan pengeluaran yang tidak sedikit diantaranta Event MTQ Se-Jawa Timur kemudian Pembangunan Pasar Besar Madiun tapi seperti yang diungkapkan ekonom di atas bahwa property dan perdagangan akan membangkitakan kondisi perekonomian madiun

Sebagai contoh: Pembangunan Mega Mall ke 5 SUN CITY Festival yang terletak di sebelah Carrefour Madiun akan di bangun sejumlah Ruko, Water Park, Mall, Hotel 10 Lantai, dan Convention Center serta Pembangunan Aton Hotel and Conference, hotel bintang 4 di jalan Mayjend Sungkono dengan tinggi 14 lantai. Dan sejumlah sarana rekreaksi keluarga yang diharapkan mampu meningkatkan

kondisi perekonomian Kota Madiun hingga beberapa tahun kedepan.

\section{Penutup}

\section{A. Simpulan}

Kota Madiun adalah sebuah kota kecil berpenduduk mencapai kurang lebih 300.000 orang Madiun berada di tengah posisi sebagai wilayah dengan jalur yang menghubungkan antara provinsi Jawa Timur - Jawa Tengah - Yogyakarta sebagai kota penghubung 3 provinsi Madiun merupakan kota persinggahan bagi sejumlah kegiatan penting di 3 provinsi terutama di bidang perdagangan dan industri dengan dijuluki sebagai "KOTA GADIS" yang berarti Kota Perdaganggan Dan Industri. Ekonomi adalah sebuah bidang kajian tentang pengurusan sumber daya material individu, masyarakat, dan negara untuk meningkatkan kesejahteraan hidup manusia. Karena ekonomi merupakan ilmu tentang perilaku dan tindakan manusia untuk memenuhi kebutuhan hidupnya yang bervariasi dan berkembang dengan sumber daya yang ada melalui pilihan-pilihan kegiatan produksi (Suherman Rosyidi, 2011: 20).

Reynold

mencoba

mendefinikan ekonomi pembangunan sebagai suatu aktifitas, atau seni, yang lebih banyak dilakukan politisi-politisi untuk mencapai tujuan-tujuannya. Kemudian ekonomi pembangunan juga merupakan sebuah studi tentang proses perunbahan 
(struktur) ekonomi yang terjadi pada kurun waktu tertentu dan jangka panjang dalam suatu masyarakat, atau Negara. Ia juga mengungkapkan bahwa ekonomika pembangunan sebagai salah satu cabang ilmu ekonomi terapan yang berisi teori ,penelitian-penelitian,dan penerapannya dalam kebijakan-kebijakan tentang masalah-masalah pembangunan.

Berdasarkan kajian awal dan atas dasar pertimbangan yang diambil oleh peneliti, maka objek penelitian adalah wilayah-wilayah atau pusat-pusat yang menjadi wilayah perkembangan ekonomi di Kota Madiun. Alasan dipilihnya objek tersebut karena banyak sekali wilayahwilayah di Kota Madiun yang bisa menjai objek perkembangan ekonomi karena perkembanganya yang sangat signifikan serta asal peneliti sendiri yang berasal dari Kota Madiun, sehingga akan mempermudah dalam pelaksanaan penelitian ini.

Letak geografis Kota Madiun sangatlah strategis hal ini didukung pada simpul jaringan jalan raya regional yang menghubungkan daerah-daerah di jawa timur dengan daerah-daerah di jawa tengah, Khususnya menghubungkan Kota Madiun dengan kota-kota besar lainya yaitu Surabaya dengan Surakarta dan Yogyakarta.Dan juga Kota Madiun merupakan wilayah dengan jaringan Kereta Api tersibuk di Pulau Jawa bagian selatan karena jalurnya menghungkan ke sejumlah kota besar seperti Surabaya - Jakarta lewat Purwokerto dan Surabaya - Bandung.

Kota Madiun merupakan salah satu wilayah pusat pertumbuhan ekonomi di Provinsi Jawa Timur. Oleh Karena itu, apapun yang terjadi di Kota Madiun akan berpengaruh pada daerah sekitarnya oleh karena itu penanaman investasi di Kota Madiun, diharapkan mampu meningkatkan pertumbuhan perekonomian setempat yang secara tidak langsung juga mendongkrak ekonomi Jawa Timur terhadap nasional.

Kota Madiun yang sebelumnya menjadi pusat wilayah dari eks-Keresidenan Madiun dan letaknya yang dekat dengan wilayah perbatasan Provinsi Jawa Tengah, merupakan dua modal positif untuk terus melakukan pembangunan yang akhirnya juga bermuara pada pertumbuhan perekonomian.

Pembagunan di bidang perdagangan, hotel, dan restoran merupakan pilihan yang tepat. Sebab, bidang usaha tersebut telah menyumbang 30 persen dari pertumbuhan ekonomi yang ada di Jawa Timur

\section{B. Saran}

1. Kepada Pemerintah Kota Madiun, selain berfokus pada pembanguna di bidang perdagangan, pendidikan, dan industri besar pemerintah juga harus mau melihat potensi dari usaha-usaha kecil baik dari sektor formal dan informal.

2. Kepada Masyarakat Kota Madiun di harapkan masyarakat juga semakin mampu berppikir dewasa dan pragmatis 
dengan mengawasi setiap pembangunan

di Kota Madiun, agar di suatu saat tetap tercipta Kota Madiun yang aman, tentram, dan nyaman.

\section{Daftar Pustaka}

Badan Pusat Statistik. 2001. Madiun Dalam Angka 2001. Madiun: Badan Pusat Statistik.

Badan Pusat Statistik. 2002. Madiun Dalam Angka 2002. Madiun: Badan Pusat Statistik.

Badan Pusat Statistik. 2003. Madiun Dalam Angka 2003. Madiun: Badan Pusat Statistik.

Badan Pusat Statistik. 2004. Madiun Dalam Angka 2004. Madiun: Badan Pusat Statistik.

Badan Pusat Statistik. 2005. Madiun Dalam Angka 2005. Madiun: Badan Pusat Statistik.

Badan Pusat Statistik. 2006. Madiun Dalam Angka 2006. Madiun: Badan Pusat Statistik.

Badan Pusat Statistik. 2007. Madiun Dalam Angka 2007. Madiun: Badan Pusat Statistik.

Badan Pusat Statistik. 2008. Madiun Dalam Angka 2008. Madiun: Badan Pusat Statistik.

Badan Pusat Statistik. 2009. Madiun Dalam Angka 2009. Madiun: Badan Pusat Statistik.

Badan Pusat Statistik. 2010. Madiun Dalam Angka 2010. Madiun: Badan Pusat Statistik.

Bagong Suyanto \& Sutinah (ed). 2005. Metode Penelitian Sosial: Berbagai
Alternatif Pendekatan. Jakarta: Kencana

Basrowi Suwandi. 2009. Memahami Penelitian Kualtatif. Jakarta: Rineka Cipta

Daldjoeni, N. 1978. Seluk Beluk Masyarakat Kota (Pusparagam Sosiologi Kota dan Ekologi Sosial). Bandung: Penerbit Alumni . 1998, Geografi Kota dan Desa. Penerbit Alumni, Bandung.

Djoko Sujarto. 1989. Faktor sejarah Perkembangan Kota Dalam Perencanaan Perkembangan Kota. Bandung. Fakultas teknik sipil dan perencanaan bandung.

Hasibuan,Nurimasyah.1987.Materi Pokok Sejarah Pemikiran Ekonomi. Jakarta: Karunika Universitas Terbuka

Hadi Sabari Yunus. 1994. Teori dan .Model Struktur Keruangan Kota. Fakultas Geografi UGM, Yogyakarta.

2000, Struktur Tata Ruang Kota. Penerbit Pustaka Pelajar. Yogyakarta.

Ilhami. 1990, Strategi Pembangunan Perkotaan di Indonesia. Penerbit Usaha Nasional, Surabaya.

Johara T Jayadinata. 1992, Tata Guna Tanah dalam Perencanaan Kota dan Wilayah. Penerbit ITB, Bandung.

Irawan. Suparmoko. 2002. Ekonomika Pembanggunan: Edisi Keenam. Yogyakarta: BPFE Fakultas Ekonomi Universitas Gajah Mada

Jawa Pos, Radar Madiun. Edisi Cetak 12 Desember 2009 
Made Wirartha. 2006. Metodologi Penelitian Sosial Ekonomi. Yogyakarta. ANDI Yogyakarta Press

Mile, Matthew E dan A Michael Huberman. 1992. Analisis Data Kualitatif. Jakarta: UI Press

Nikiuluw,Risty. Dkk. 2011.Jurnal Pendidikan.Madiun:IKIP PGRI Madiun

Prayitno, Hadi. 1986. Ekonomika Pembangunan Edisi Pertama. Yogyakarta: BPFE Fakultas Ekonomi Universitas Gajah Mada

Rosyidi, Suherman.2011. Pengantar Teori Ekonomi: Pendekatan Kepada Teori Ekonomi Mikro dan Makro.Jakarta: Rajawali Press

Situs Resmi Badan Penanaman Modal RI Kota Madiun http://regionalinvestment.bkpm.go.id /newsipid/id/ekonomipdrb.php?ia=3 577\&is $=43$

Situs Resmi Badan Pusat Statistik Kota Madiun http://madiunkota.bps.go.id/index.ph $\mathrm{p} /$ beranda

Subri, Mulyadi. 2003. Ekonomi Sumber Daya Manusia. Jakarta: PT RajaGrafindoPersada.

Sugiyono. 2010. Metodologi Penelitian Pendidikan (Pendekatan Kuantitatif, Kualitatif, dan $R \& D$ ). Bandung: CV Alfabeta

Sutopo. 2002. Metodologi Penelitian Kualitatif. Surakarta: Universitas Sebelas Maret Press

Internet:

http://ciptakarya.pu.go.id/profil/profil/bar at/jatim/madiun.pdf

http://www.skyscrapercity.com/showthrea d.php?t=1442664\&page $=44$ 